\title{
Lactation performance of Holstein cows treated with 2 formulations of recombinant bovine somatotropin in a large commercial dairy herd in Brazil
}

\author{
J. P. G. de Morais, ${ }^{* 1}$ A. P. da S. Cruz, $†$ N. S. Minami, $\dagger$ L. P. Veronese, ${ }^{*}$ T. A. Del Valle, ${ }^{*}$ and J. Araminił \\ *Departamento de Biotecnologia Vegetal e Animal, Universidade Federal de São Carlos, Campus Araras, Araras, SP 13600-970, Brazil \\ †Fundação de Apoio Institucional (FAl), Campus São Carlos, São Carlos, SP 13565-905, Brazil \\ ¥Novometrix Research Inc., 4564 Nassagaweya-Puslinch Townline, Moffat, Ontario, Canada LOP 1J0
}

\begin{abstract}
The objectives of this controlled study were to compare the effects of 2 different formulations of recombinant bovine somatotropin (rbST) on milk yield, milk composition (fat and protein), milk somatic cell count, and body condition score (BCS) among dairy cattle in a large commercial herd. Regulatory approved 500-mg zinc sesame oil base rbST (ZSO-rbST; Elanco Animal Health, Greenfield, IN) and vitamin E lecithin base rbST (VEL-rbST; LG Life Sciences, Seoul, South Korea) formulations were administered per the manufacturers' recommendations every $14 \mathrm{~d}$ over 17 injection cycles starting at 57 to $70 \mathrm{~d}$ of lactation (90 cows per rbST group). Control cows $(\mathrm{n}=60)$ received no $\mathrm{rbST}$. Somatotropin-treated animals (VEL-rbST and ZSOrbST combined) had increased average milk yield and protein percentage and lower average BCS compared with control cows. For primiparous cows, average milk yield was $37.75 \mathrm{~kg} / \mathrm{d}$ with the ZSO-rbST treatment and $35.72 \mathrm{~kg} / \mathrm{d}$ with the VEL-rbST treatment. For multiparous cows, average milk yield was $40.13 \mathrm{~kg} / \mathrm{d}$ with the ZSO-rbST treatment and $38.81 \mathrm{~kg} / \mathrm{d}$ with the VEL-rbST treatment. There were no differences in milk fat percentage between VEL-rbST and ZSO-rbST treatments, but milk protein content was greater with VEL-rbST treatment than with ZSO-rbST treatment. Nonetheless, cows treated with ZSO-rbST yielded more kilograms of fat and protein per day than cows treated with VEL-rbST. No significant differences in BCS were found between both rbST treatment groups. The differential increase in milk yield between cows treated with ZSO-rbST and VEL-rbST was driven by rbST response differences both within the 14-d cycle and throughout the 17 injection cycles. The cows treated with VELrbST demonstrated a more variable 14-d milk yield response curve, with more pronounced valleys between
\end{abstract}

Received September 6, 2016.

Accepted February 28, 2017.

${ }^{1}$ Corresponding author: jozivaldo@cca.ufscar.br injections compared with the ZSO-rbST formulation. In addition, only the ZSO-rbST treatment was effective in modifying the lactation persistency compared with control cows. Compared with the VEL-rbST formulation, the ZSO-rbST formulation yielded more kilograms of milk, fat, and protein with less milk variation throughout the seventeen 14-d lactation cycles for both primiparous and multiparous cows.

Key words: somatotropin, lactation performance, lactation persistency, Boostin, Lactotropin

\section{INTRODUCTION}

Bovine growth hormone is a naturally occurring hormone in cattle that is responsible for growth regulation and milk production (Bauman, 1999). Recombinant bST (rbST) is a synthetically derived formulation of this hormone that has been developed to increase milk production efficiency in dairy cows and profitability in dairy herds. Recombinant bST increases lactation milk yield by altering the lactation curve. Not only does milk yield increase immediately upon rbST administration, but milk yield is maintained at a higher persistency throughout the lactation cycle compared with cows not supplemented with rbST (van Amburgh et al., 1997).

A large body of scientific evidence demonstrates that rbST treatment of dairy cattle results in increased milk production (Downer et al., 1993; Huber et al., 1997). A 2014 meta-analysis review of the effects of rbST reported that it increases milk production by $4 \mathrm{~kg} /$ cow per day over the course of a lactation (St-Pierre et al., 2014). More importantly for dairy producers, rbST increases profitability. A recently published study estimates an average cost savings from the use of rbST among New York dairy farms of $5.5 \% / \mathrm{kg}$ of milk produced, or $\$ 2.67 / 100 \mathrm{~kg}$ of milk produced in 2013 (Tauer, 2016).

Insulin-like growth factors are known to be important mediators of many biological processes, including growth, lactation, reproduction, and health (McGuire et al., 1992). Numerous studies have demonstrated that 
an increase in blood bST levels upregulates the production of IGF-1, as measured in both milk and blood. This increase in IGF-1 levels is the primary driver that enhances milk production in cows treated with various rbST formulations (Schams, 1989; Vicini et al., 1991; Azizan et al., 1994; Daxenberger et al., 1998; Collier et al., 2008; Castigliego et al., 2009).

There are 2 commercial rbST products in Brazil: a zinc sesame oil base formulation (ZSO-rbST; Lactotropin, Elanco Animal Health, Greenfield, IN) and a vitamin E lecithin base formulation (VEL-rbST; Boostin-S, LG Life Sciences, Seoul, South Korea). Despite the fact that rbST is one of the most widely researched hormones used in animal production and that numerous studies have investigated the effect of rbST supplementation on endocrine profiles, to our knowledge, no controlled research compares the effects of both rbST formulations on milk yield response for a full lactation in a commercial intensive dairy herd. Thus, in those countries where both formulations are licensed, dairy producers have very little information to help them decide which product is best suited for their farm.

The objectives of this controlled study were to compare the effects of both rbST formulations (ZSO-rbST and VEL-rbST) on milk yield, milk composition (fat and protein), milk SCC, and BCS among dairy cattle in a commercial dairy herd in Brazil. Of particular interest were the daily responses to rbST within the 14-d injection cycles and the overall 14-d response among the 17 injection cycles.

\section{MATERIALS AND METHODS}

\section{Experimental Design}

This study was conducted between September 2013 and December 2014 at the Fazenda Santa Rita, Descalvado, São Paulo, Brazil (47 $\left.37^{\prime} 10^{\prime \prime} \mathrm{W}, 21^{\circ} 54^{\prime} 14^{\prime \prime} \mathrm{S}\right)$, on a large commercial freestall operation with 1,700 Holstein Friesian cows. All study cows received the same management practices. The region's weather is classified as a humid subtropical climate, with an average daily temperature of $21.4 \pm 3.32^{\circ} \mathrm{C}$ (mean $\pm \mathrm{SD}$ ) and a relative humidity of $76.3 \pm 9.8 \%$ during the trial.

Cows were fed a TMR formulated according to the NRC's nutrient requirements for dairy cattle (NRC, 2001) that consisted of the following primary ingredients on a DM basis: corn silage $(37.6 \%)$, high-moisture corn $(11.2 \%)$, soybean meal $(8.3 \%)$, ground corn grain (8.1\%), dried citrus pulp (7.5\%), and roasted soybeans $(7.0 \%)$ in addition to a vitamin and mineral premix $(3.6 \%)$. The experimental unit in the study was the individual cow. Ninety cows were enrolled in each of the $2 \mathrm{rbST}$ treatment groups and 60 cows were enrolled in the control (no treatment) group, for a total of 240 cows.

Each cow received pretreatment health, reproductive, body condition, and lameness exams between $\mathrm{d}$ 37 and 50 postpartum by a farm veterinarian who was not part of the research team. Study inclusion criteria were as follows. Cows had to be 57 to $70 \mathrm{~d}$ postpartum at the start of the treatment period and have been deemed healthy by veterinary examination. Milk production had to be $\geq 25 \mathrm{~kg} / \mathrm{d}$ measured as an average of the first 7 consecutive days out of a 10-d period immediately before the first injection. Body condition score had to be $\geq 2.5$ on a 5-point scale (Pennington, 2003), and a lameness evaluation score had to be 2 or less on a 5-point scale (Branine et al., 2014). Each cow had to be free of uterine or ovarian pathology and have an SCC of $\leq 200,000 / \mathrm{mL}$ of milk. Each cow could not have had a single case of clinical mastitis (described as visibly abnormal milk) before the start of the study period (57-70 d postpartum) or subclinical mastitis based on milk cultures conducted between d 46 and 59 postpartum for Streptococcus agalactiae and Staphylococcus aureus.

Every $14 \mathrm{~d}$, a new group of cows (15 groups in total) entered the study as they came into milk production and met the inclusion criteria. A randomization process was used to assign cattle to each treatment group. Cows were ranked by the average daily milk yield of the first 7 consecutive days out of a 10-d period interval immediately before the first injection. The ranked production list of cows was blocked into randomized groups of 3 ( $2 \mathrm{rbST}$ treatments and a control). In every third block, no cow was assigned to the control group as the number of animals in the control group corresponded to two-thirds of the rbST-treated groups. This randomization procedure was applied separately for primiparous and multiparous cows. Overall, the study included $35 \%$ primiparous and $65 \%$ multiparous cows.

\section{Experimental Procedures}

The 3 treatment formulations compared were ZSOrbST, VEL-rbST, and no treatment (controls). Each rbST treatment group was given $500 \mathrm{mg}$ of active rbST every $14 \mathrm{~d}$ starting at 57 to $70 \mathrm{~d}$ postcalving according to the manufacturer's directions. For each cow, the study was terminated when 1 of the following conditions was met: (1) after 17 cycles of rbST injections (approximately $300 \mathrm{~d}$ after calving), (2) when the cow reached the seventh month of gestation, or (3) when production decreased below $12 \mathrm{~kg} / \mathrm{d}$. In addition, control cows not confirmed pregnant at 240 DIM with a milk production of $<25 \mathrm{~kg} / \mathrm{d}$ were released from the 
study and treated with rbST per usual farm practice to sustain production for longer before culling.

The same administration route was used for each rbST formulation and involved a subcutaneous injection from a single dose applied. The injection site alternated at each treatment. Control cows did not receive a sham injection. Animals were milked 3 times/d. Individual animal milk yields were automatically recorded electronically for each milking. Body condition score was measured every $14 \mathrm{~d}$ on all cows at the start of each injection cycle. Milk samples were collected every $2 \mathrm{wk}$ on d 11 of the injection cycle and analyzed for fat and protein by infrared absorption using a MilkoScan FT+ (Foss Electric, Hillerød, Denmark) and for SCC by flow cytometry using a Fossomatic FC (Foss Electric).

\section{Statistical Analysis}

Theoretically, data could be analyzed as a single linear mixed model, but the size of the resulting model exceeded the capabilities of contemporary high-speed computers, making this approach impossible. Hence, statistical analyses had to be segmented into 3 complementary sets. All analyses were conducted using SAS 9.3 (SAS Institute Inc., 2011).

Analyses Across the 17 Injection Cycles. Measurements were first averaged within each cow and cycle. This resulted in a $2 \times 3 \times 17$ factorial arrangement of treatments with 2 parities, 3 rbST treatments (an unsupplemented control and $2 \mathrm{rbST}$ formulations), and seventeen 2 -wk cycles. The resulting data were analyzed as a split plot design with repeated measurements, with parity as the main plot factor and rbST treatments in the subplot, arranged in an incomplete randomized block design. The resulting model was

$$
\begin{aligned}
y_{i j k l m}= & \mu+P_{i}+b_{j: i}+T_{k}+P T_{i k}+c_{l: i j k} \\
& +B_{1}\left(X_{l: i j k}-\bar{X}_{i}\right)+C_{m}+P C_{i m}+T C_{k m} \\
& +P T C_{i k m}+e_{i j k l m}
\end{aligned}
$$

with

$$
b_{j: i} \approx N\left(0, \sigma_{b}^{2}\right), c_{l: i j k} \approx N\left(0, \sigma_{c}^{2}\right), e_{i j k l m} \approx M V N(0, \mathbf{R}),
$$

where $y_{i j k l m}$ is the value of the dependent variable; $\mu$ is the overall population mean; $P_{i}$ is the fixed effect of the $i$ th parity $(i=1,2) ; b_{j: i}$ is the random effect of the $j$ th block within the $i$ th parity ( $j=1$ to 30 for primiparous cows and $j=1$ to 60 for multiparous cows); $T_{k}$ is the fixed effect of the $k$ th $\operatorname{rbST}$ treatment $(k=1,2,3) ; c_{l: i j k}$ is the random effect of the $l$ th cow within the $i$ th parity, $j$ th block, and $k$ th treatment; $B_{1}$ is a fixed effect regres- sion coefficient; $X_{l: i j k}$ is the covariate measurement on $\operatorname{cow}_{l: i j k} ; \bar{X}_{i}$ is the mean of the covariate measurements on animals of parity $i ; C_{m}$ is the fixed effect of the $m$ th cycle, $m=1, \ldots, 17 ; e_{i j k l m}$ is the random residual error; $P T_{i k}, P C_{i m}, T C_{k m}$, and $P T C_{i k m}$ are interaction terms; $N$ is the normal distribution; $\sigma_{b}^{2}$ is the variance due to blocks; $\sigma_{c}^{2}$ is the variance due to cows; $M V N$ is the multivariate normal; and $\mathbf{R}$ is the variance-covariance matrix of residuals due to the repeated measurements (i.e., 17 cycles) on each cow.

Various structures of the error covariance matrix R were fitted: compound symmetry, autoregressive, Huynh-Feldt, Toeplitz, and unstructured. The autoregressive structure was chosen based on the Bayesian information criterion. When feasible, the KenwardRoger corrections to the degrees of freedom were applied (Kenward and Roger, 1997).

In Equation 1, the covariances were the average measurements on each of the dependent variables (i.e., milk and components yield, milk composition, and so on) in the week preceding the allocation of the animals to their respective rbST treatment. The covariate adjustments are expressed as deviations from the means of the covariates for each of the 2 parities so as not to include some of the parity effects in the covariates. The effect of treatments was decomposed into 2 orthogonal contrasts: (1) the 2 bST treatments versus the control, and (2) ZSO versus VEL. Other comparisons were made using Fisher's protected least significant difference.

Analyses Within the Injection Cycle. Measurements were first averaged within each cow and day of cycle. This resulted in a $2 \times 3 \times 14$ factorial arrangement of treatments ( 2 parities, 3 rbST treatments, and $14 \mathrm{~d}$ in each cycle). A model similar to Equation 1 was then fitted, but with the effect of day of the cycle $\left(D_{m}\right)$ replacing the term $C_{m}$ as well as all interactions of $C_{m}$ with the other fixed effects.

Analyses to Determine Average Persistency. The same data as those used to fit Equation 1 were used in a modified mixed linear model when the discrete effect of the cycle $C_{m}$ was replaced by cycle expressed as a continuous variable. In essence, this is simply a linear regression of milk yield on cycle number for each of the 6 parity $\times$ treatment subclasses while accounting for the design structure elements (i.e., blocks and cows) and the correlation of the error terms within a cow. Each of the 6 slope estimates are then simple estimates of the average lactation persistency of the animals in each parity $\times$ treatment subclass. Here, persistency is expressed as the average production decline per cycle (i.e., per fortnight) in absolute terms (i.e., as $\mathrm{kg} / \mathrm{d}$ change per cycle) and not as a percentage or prior yield (Cole and VanRaden, 2006). Orthogonal 
contrasts were used to assess the effect of treatments on the average persistency across cycles. This approach is not an attempt to identify a correct lactation curve for each of the parity $\times$ treatment subclasses but rather to estimate the average production decline over the 17 cycles for each of the 6 parity $\times$ treatment subclasses.

\section{RESULTS}

\section{Overall Results}

Seventy percent of the cows from all treatment groups combined completed all 17 injection cycles, with no significant differences among treatment groups (data not shown). Within the group of cows that did not complete the 17 injection cycles (30\%), the reasons for not doing so were gestation length $(69 \%)$, health problems and culling (20\%), low production (7\%), and death $(4 \%)$. Prior to the treatment period we found no significant differences among control, VEL-rbST, and ZSO-rbST cows for milk yield $(P=0.99)$, milk fat content $(P=0.37)$, milk fat yield $(P=0.32)$, milk protein content $(P=0.51)$, milk protein yield $(P=$ $0.69)$, or the $\operatorname{logSCC}(P=0.61)$. The milk production for the primiparous cows during the pretreatment period averaged $35.98,35.59$, and $35.69 \mathrm{~kg} / \mathrm{d}$ for control, VEL-rbST, and ZSO-rbST cows, respectively. The milk production for multiparous cows during the pretreatment period averaged $43.88,44.14$, and $44.06 \mathrm{~kg} / \mathrm{d}$ for control, VEL-rbST, and ZSO-rbST cows, respectively. Similarly, the BCS of the primiparous and multiparous cows for the control, VEL-rbST, and ZSO-rbST cows during the pretreatment period did not differ $(P=$ $0.55)$. Overall production results during the treatment periods for the 3 treatment groups are presented in Table 1. During the treatment period, rbST-treated animals (VEL-rbST and ZSO-rbST combined) had increased average milk yield as well as milk fat and protein yields $(P<0.001)$ compared with controls. Milk fat percentage was decreased by rbST treatments $(P<0.001)$. In contrast, milk protein percentage was increased by rbST treatment $(P<0.001)$. Both VELrbST and ZSO-rbST had no effect on $\operatorname{logSCC}(P=$ $0.946)$, and both treatments reduced the average BCS compared with control cows $(P<0.001$; Table 1$)$. The primiparous cows treated with ZSO-rbST yielded 37.75 $\mathrm{kg} / \mathrm{d}$, which was different from the $35.72 \mathrm{~kg} / \mathrm{d}$ yielded by the cows treated with VEL-rbST $(P=0.003)$. The multiparous cows treated with ZSO-rbST yielded 40.13 $\mathrm{kg} / \mathrm{d}$, which was different from the $38.81 \mathrm{~kg} / \mathrm{d}$ yielded by the cows treated with VEL-rbST $(P=0.011)$. The difference in milk yield response between the ZSO-rbST and VEL-rbST treatments was not affected by parity $(P=0.164)$.

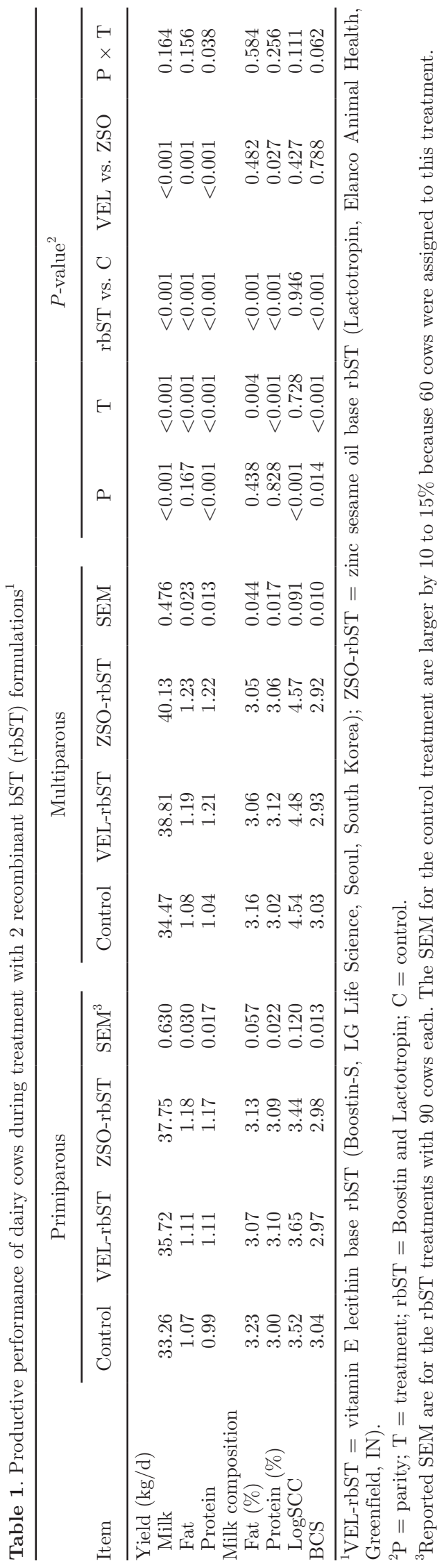




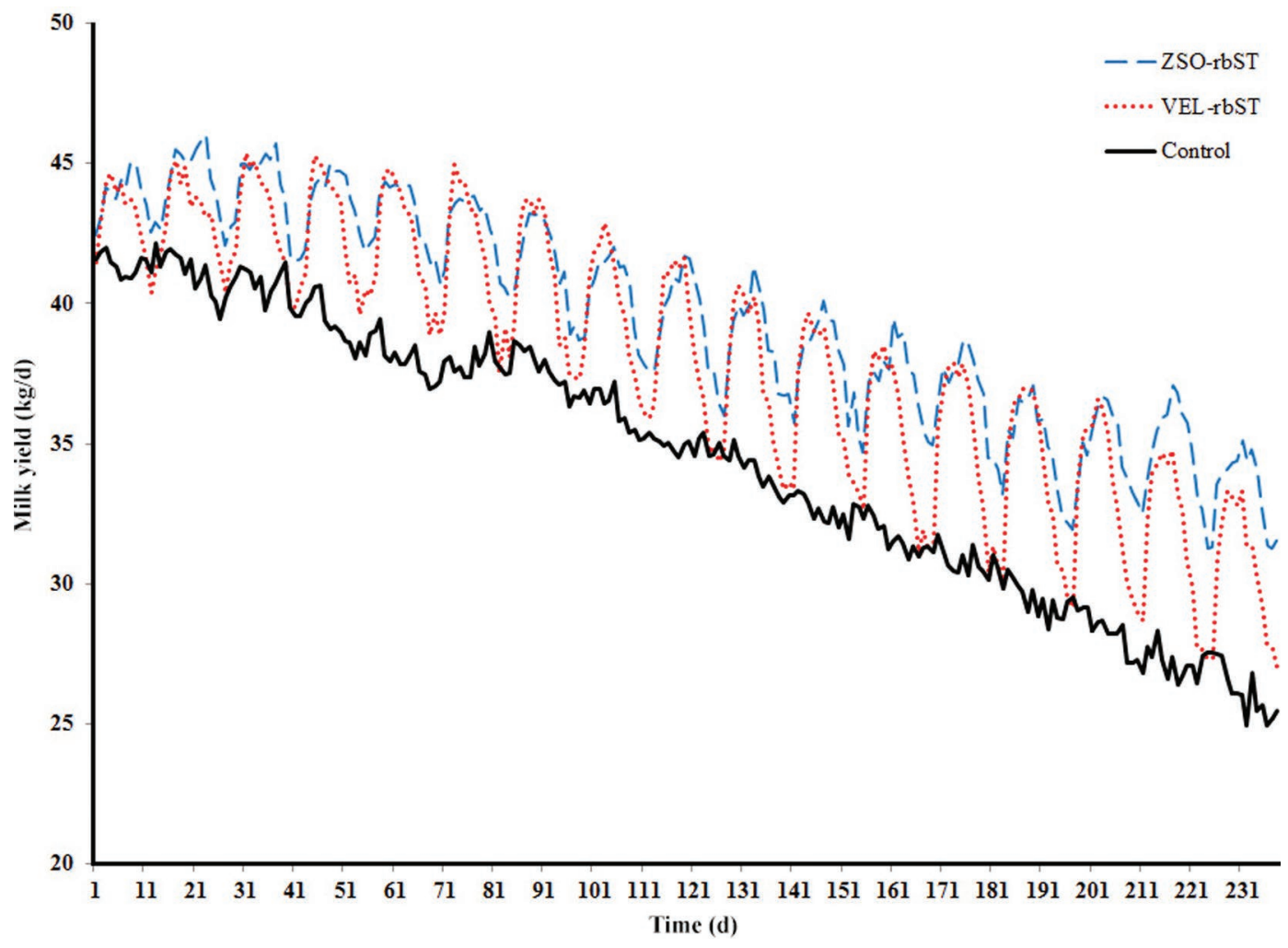

Figure 1. Mean milk yield $(\mathrm{kg} / \mathrm{d})$ among dairy cows treated with vitamin E lecithin base (VEL) and zinc sesame oil base (ZSO) recombinant bST (rbST) over the entire treatment period. Somatotropin injections were given every $14 \mathrm{~d}$ for 17 cycles starting at 57 to $70 \mathrm{~d}$ postcalving. Color version available online.

Yields of fat and protein were also different for both primiparous and multiparous rbST-treated cows compared with control cows $(P<0.001$; Table 1$)$. The cows treated with ZSO-rbST yielded more kilograms of fat $(P=0.001)$ and protein $(P<0.001)$ per day compared with cows treated with VEL-rbST, and a parity $\times$ treatment interaction was found for protein yield $(P=$ 0.038 ). Figure 1 shows daily milk yield for dairy cows among the 3 treatment groups over the entire treatment period (17 injection cycles).

\section{Effect of rbST Formulation on Milk Protein, Fat Composition, and SCC}

As demonstrated in Table 1, when compared with the control, both VEL-rbST and ZSO-rbST treatments affected milk fat percentage $(P<0.001)$ and milk protein percentage $(P<0.001)$. No differences in milk fat percentage were found between VEL-rbST and ZSOrbST treatments $(P=0.482)$; however, milk protein percentage differed between VEL-rbST and ZSO-rbST treatments $(P=0.027)$. Somatotropin treatments did not affect SCC compared with control cows $(P=$
0.946), and no $\operatorname{logSCC}$ differences were found between VEL-rbST and ZSO-rbST treatments $(P=0.427)$.

\section{Effect of rbST Formulation on Milk Yield Within the 14-d Injection Cycle}

Figures $2 \mathrm{~A}$ and B present least squares means of milk yield for each day of the 14-d injection cycle among the 3 treatment groups for primiparous and multiparous cows, respectively. When comparing treatment cows with control cows, primiparous cows treated with ZSO-rbST had increased $(P<0.05)$ milk yield in all days of the injection cycle when day was evaluated as a categorical variable. In contrast, primiparous cows treated with VEL-rbST had increased $(P<0.05)$ milk yield only for d 2 to 9. Similarly, when comparing treatment cows with control cows, multiparous cows treated with ZSO-rbST had increased $(P<0.05)$ milk yield in all days of the injection cycle, but multiparous cows treated with VEL-rbST had increased $(P<0.05)$ milk yield only for $\mathrm{d} 2$ to 11 . When the $2 \mathrm{rbST}$ formulations were compared, cows treated with ZSO-rbST had a higher $(P<0.05)$ milk yield than did cows treated 

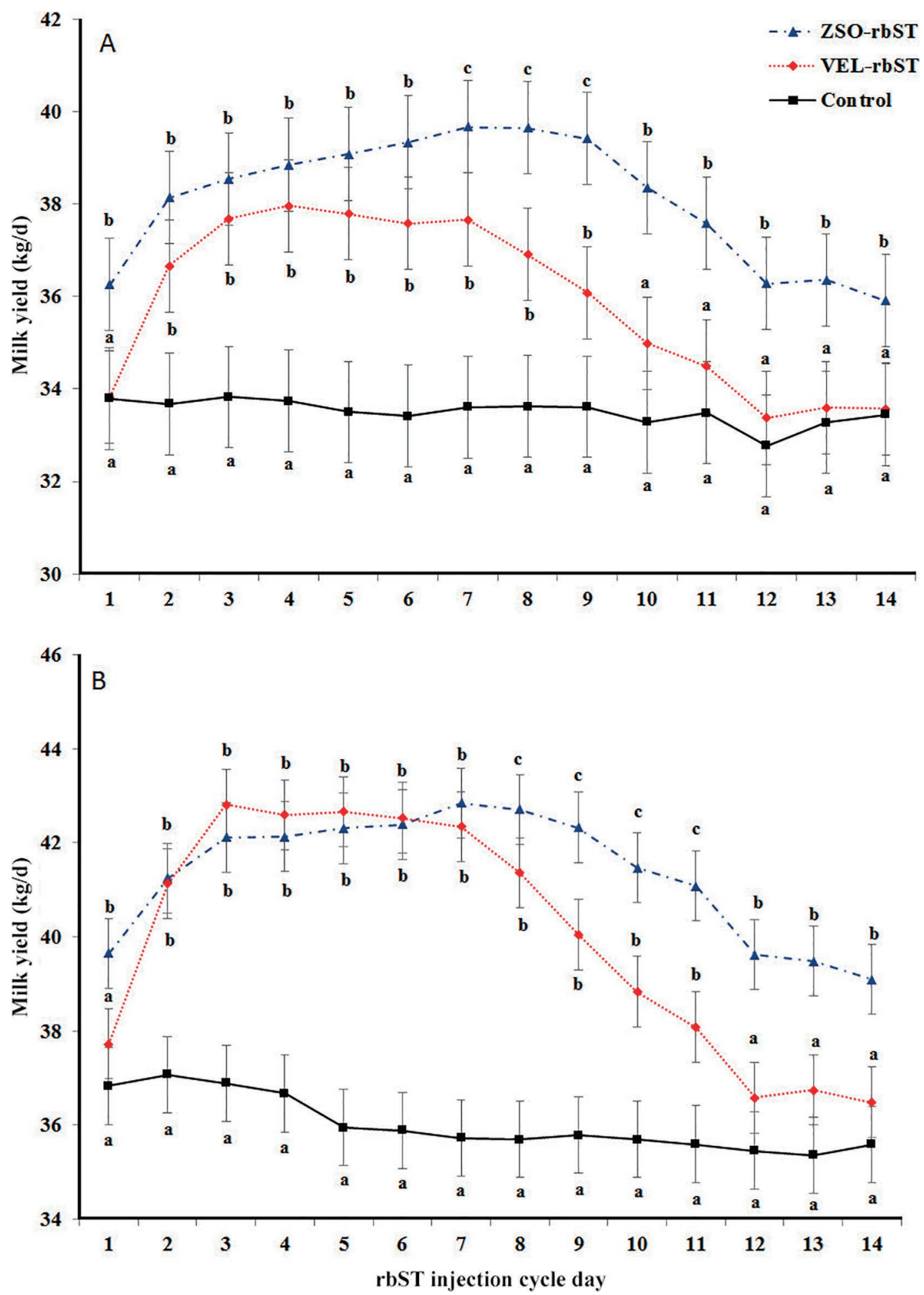

Figure 2. Least squares means and standard error of the mean of milk yield (kg/d) for (A) primiparous and (B) multiparous cows treated with vitamin E lecithin base (VEL) and zinc sesame oil base (ZSO) recombinant bST (rbST) or not treated (control) within $14 \mathrm{~d}$ of the 17 injection cycles. Daily means within a cycle with different letters $(\mathrm{a}-\mathrm{c})$ differ $(P<0.05)$. Color version available online. 
with VEL-rbST for $\mathrm{d} 1$ and 7 to 14 of the 14-d cycle and $\mathrm{d} 1$ and 8 to 14 of the 14-d cycle for primiparous and multiparous cows, respectively.

\section{Effect of rbST Formulation on Milk Yield Persistency}

When examining the effects of rbST by injection cycle (as a categorical variable), we found that for primiparous cows (Figure 3A) the ZSO-rbST treatment significantly increased $(P<0.05)$ milk production compared with the control from cycles 4 through 17 . The VEL-rbST treatment significantly increased $(P$ $<0.05)$ milk production compared with the control in cycles $4,5,7,8,12,15$, and 16 (Figure 3A). The ZSOrbST treatment significantly increased $(P<0.05)$ milk production compared with the VEL-rbST treatment in cycles 4,10 to 13 , and 17 (Figure 3A). Similarly, when examining the effects of rbST by injection cycle (as a categorical variable), we found that for multiparous cows (Figure 3B) the ZSO-rbST treatment significantly increased $(P<0.05)$ milk production compared with the control for all 17 cycles. In contrast, the VELrbST treatment significantly increased $(P<0.05)$ milk production of the multiparous cows compared with control cows in cycles 12, 13, 16, and 17 (Figure 3B). The ZSO-rbST treatment significantly increased $(P<$ $0.05)$ milk production of multiparous cows compared with the VEL-rbST treatment in cycles 12, 13, 16, and 17 (Figure 3B). The milk persistency data across the seventeen 14-d cycle treatments are shown in Table 2. Although both rbST treatments numerically modified the average decline in daily milk yield compared with the control, only the ZSO-rbST treatment significantly improved the lactation persistency $(P<0.01)$. When analyzing the data by parity, only the multiparous cows treated with ZSO-rbST significantly differed from the control group. Nonetheless, no parity $\times$ treatment interaction was found ( $P=0.71$; Table 2$)$.

\section{Effect of rbST Formulation on Cow BCS}

The overall BCS information is shown in Table 1. The BCS was affected by both VEL-rbST and ZSOrbST treatments $(P<0.001)$ when compared with the control. No differences were found between the effect of VEL-rbST and ZSO-rbST treatments on BCS $(P=$ 0.788).

During the treatment period, primiparous control cows (Figure 4A) gained 0.10 point in BCS, starting at 2.98 and finishing the treatment period at 3.08 (1-to-5 scale; Pennington, 2003) and averaging 3.04 throughout the entire trial (Table 1). Primiparous cows treated with ZSO-rbST and those treated with VEL-rbST gained 0.05 point throughout the entire treatment period (Figure 4A). Primiparous cows treated with ZSO-rbST started at 2.96 and finished at 3.01, whereas primiparous cows treated with VEL-rbST started at 2.93 and finished at 2.98. During the treatment period multiparous control cows (Figure 4B) gained 0.42 point in BCS, starting at 2.86 and finishing the treatment period at 3.28. Multiparous cows treated with ZSOrbST gained 0.13 point in BCS, and those treated with VEL-rbST gained 0.19 point in BCS during the treatment period. Multiparous cows treated with ZSO-rbST started at 2.85 and finished at 2.97, and primiparous cows treated with VEL-rbST started at 2.84 and finished at 3.04. No significant differences in BCS values were found between the $2 \mathrm{rbST}$ formulations (Table 1 ). The BCS of multiparous cows treated with rbST began to diverge $(P<0.05)$ from that of control cows starting on injection cycles 6 and 7 (Figure 4B).

\section{DISCUSSION}

This is the first study to our knowledge that investigates and documents significant differences in milk yield responses through a full lactation for dairy cows supplemented with ZSO-rbST and VEL-rbST when evaluated on a commercial dairy operation. Overall milk yield was significantly increased among primiparous and multiparous cows treated with ZSO-rbST over a 238-d treatment period when compared with cows treated with VEL-rbST. As a consequence, more kilograms of milk fat and protein were produced per day when both primiparous and multiparous cows were supplemented with ZSO-rbST compared with VEL-rbST. These increases in fat and protein yields are consistent with a recent publication (St-Pierre et al., 2014). Under the conditions tested in this study, milk fat percentage decreased due to rbST supplementation (probably because of a dilution effect), whereas the milk protein content increased; similar increases have been reported in the literature (Barbano et al., 1992). The parity $\times$ treatment interaction for milk protein yield reported in this study could be a consequence of the additional protein demand due to body protein growth during the first lactation (St-Pierre et al., 2014). In the current study, SCC did not differ significantly between control and rbST-treated cows, as it has been reported in the literature (St-Pierre et al., 2014). In a same fashion, VEL-rbST and ZSO-rbST treatments did not differ.

In this research, we clearly demonstrated significant differences in milk yields among the treatment groups. Over the course of the 238-d treatment period, both primiparous and multiparous rbST-treated cows produced more milk compared with controls. We observed an increase in milk yield consistent with rbST responses reported by a recent publication (St-Pierre et al., 

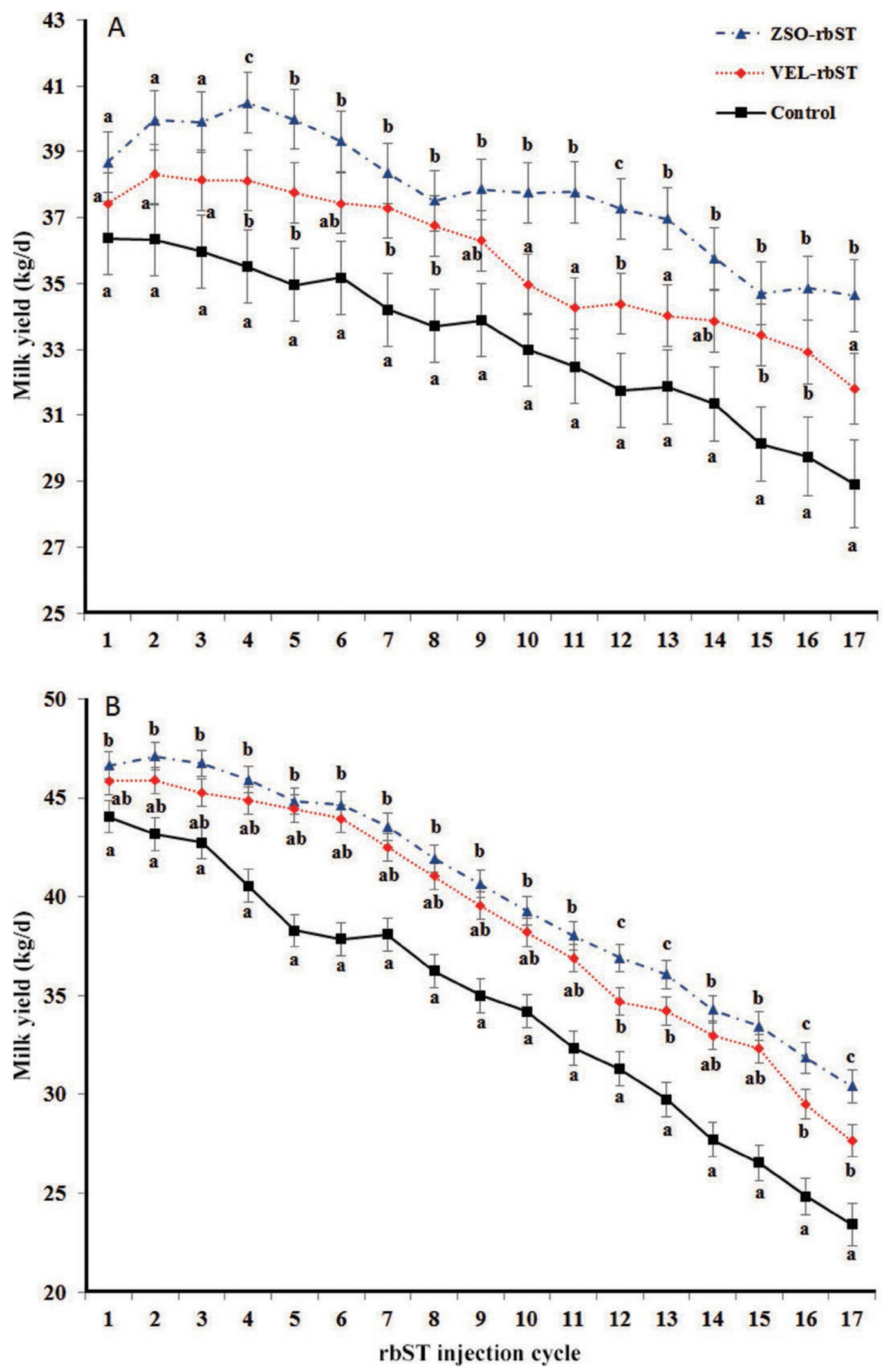

Figure 3. Least squares means and standard error of the mean of milk yield (kg/d) for (A) primiparous and (B) multiparous cows treated with vitamin E lecithin base (VEL) and zinc sesame oil base (ZSO) recombinant bST (rbST) or not treated (control) over seventeen 14-d injection cycles. Cycle means with different letters $(\mathrm{a}-\mathrm{c})$ differ $(P<0.05)$. Color version available online. 
Table 2. Milk yield persistency (average slopes) across cycles among control cows and cows treated with 2 recombinant bST (rbST) formulations over seventeen 14-d injection cycles ${ }^{1}$

\begin{tabular}{|c|c|c|c|c|}
\hline \multirow[b]{2}{*}{ Item } & \multicolumn{3}{|c|}{ Treatment } & \multirow[b]{2}{*}{$\mathrm{SEM}^{2}$} \\
\hline & Control & VEL-rbST & ZSO-rbST & \\
\hline $\begin{array}{l}\text { All cows } \\
\text { Primiparous } \\
\text { Multiparous }\end{array}$ & $\begin{array}{l}-0.8622^{\mathrm{a}} \\
-0.4547^{\mathrm{a}} \\
-1.2697^{\mathrm{a}}\end{array}$ & $\begin{array}{l}-0.7339^{\mathrm{ab}} \\
-0.3542^{\mathrm{a}} \\
-1.1135^{\mathrm{ab}}\end{array}$ & $\begin{array}{l}-0.6549^{\mathrm{b}} \\
-0.2884^{\mathrm{a}} \\
-1.0214^{\mathrm{b}}\end{array}$ & $\begin{array}{l}0.046 \\
0.073 \\
0.056\end{array}$ \\
\hline \multicolumn{5}{|c|}{$\begin{array}{l}\text { a,b Slopes within a row with different superscripts differ }(P<0.01) \text {. Significance for parity effect }<0.001 \text { and } \\
\text { parity } \times \text { treatment }=0.71 \text {. }\end{array}$} \\
\hline \multicolumn{5}{|c|}{$\begin{array}{l}{ }^{1} \text { Persistency is expressed as the average decline in daily milk yield }(\mathrm{kg} / \mathrm{d}) \text { per cycle }(14 \mathrm{~d}) . \text { VEL-rbST }=\text { vita- } \\
\text { min E lecithin base rbST (Boostin-S, LG Life Science, Seoul, South Korea); ZSO-rbST = zinc sesame oil base } \\
\text { rbST (Lactotropin, Elanco Animal Health, Greenfield, IN). }\end{array}$} \\
\hline \multicolumn{5}{|c|}{$\begin{array}{l}{ }^{2} \text { Reported SEM are for the rbST treatments with } 90 \text { cows each. The SEM for the control treatment are larger } \\
\text { by } 23 \text { to } 25 \% \text { because } 60 \text { cows were assigned to this treatment. }\end{array}$} \\
\hline
\end{tabular}

2014). When the $2 \mathrm{rbST}$ formulations were compared, primiparous cows treated with ZSO-rbST produced on average $2.03 \mathrm{~kg} / \mathrm{d}$ more milk than those treated with VEL-rbST, or approximately $483 \mathrm{~kg}$ more milk over the entire 238-d treatment period. For multiparous cows, those treated with ZSO-rbST produced on average 1.32 $\mathrm{kg} / \mathrm{d}$ more milk than those treated with VEL-rbST, or approximately $314 \mathrm{~kg}$ more milk over the entire 238$\mathrm{d}$ treatment period. Within and between the $17 \mathrm{rbST}$ injection cycles, milk yield analyses help reveal the drivers behind these differences.

As demonstrated in Figures 2A and B, clear differences were found in daily milk yields between the cows treated with ZSO-rbST and those treated with VELrbST within the 14-d injection cycles. For primiparous cows, the ZSO-rbST treatment was effective in increasing milk production within the 14-d cycle above that of control cows throughout the cycle period, whereas the VEL-rbST treatment increased milk production during only part of the cycle compared with control cows. Similarly, for multiparous cows, although those treated with ZSO-rbST and VEL-rbST had different milk yields on d 1 of the cycle, cows in both rbST treatments had similar milk peak yields. Those treated with VEL-rbST started to decline on d 8 and showed no difference from control cows on d 12 of the cycle. In contrast, those treated with ZSO-rbST maintained the difference with the control cows throughout the 14-d cycle, demonstrating a more sustainable 14-d milk yield response compared with the VEL-rbST treatment. A previous study by Bauman et al. (1989) examining the effects of the same ZSO base rbST formulation observed a comparable 14-d milk yield response curve with a peak on d 7 (midway through the injection cycle). In our study, the ZSO-rbST formulation had longer persistency within the injection cycle compared with the VEL-rbST formulation.

Analysis of the effects of rbST formulation on daily milk yield across the 17 injection cycles demonstrated an additional important difference between cows treated with ZSO-rbST and those treated with VEL-rbST. For primiparous cows, the ZSO-rbST treatment was able to maintain increased levels of daily milk yield over 6 cycles compared with the VEL-rbST treatment. Likewise, multiparous cows supplemented with ZSOrbST had a greater response than those supplemented with VEL-rbST in cycles 12, 13, 16, and 17 . When comparing the rbST-treated primiparous cows with control primiparous cows, the ZSO-rbST treatment significantly increased milk production in $82.4 \%$ of the cycles (14/17), whereas the VEL-rbST treatment significantly increased milk production in $41.2 \%$ (7/17; Figure $3 \mathrm{~A})$. Also, compared with multiparous control cows, multiparous cows treated with ZSO-rbST produced more milk during $100 \%$ of the cycles, whereas those treated with VEL-rbST produced more milk in only $23.5 \%$ of the cycle treatment periods $(4 / 17$; Figure $3 \mathrm{~B})$. In line with the previous observations, the milk yield persistency analysis across cycles (Table 2) showed that only the ZSO-rbST treatment was effective in modifying the average decline in daily milk yield per unit cycle. When the average slopes were analyzed by parity, primiparous control cows decreased $0.45 \mathrm{~kg} / \mathrm{d}$ per cycle, primiparous cows treated with VEL-rbST decreased $0.35 \mathrm{~kg} / \mathrm{d}$ per cycle, and primiparous cows treated with ZSO-rbST decreased $0.29 \mathrm{~kg} / \mathrm{d}$ per cycle, but treatments did not differ. In contrast, the $1.02 \mathrm{~kg} / \mathrm{d}$ per cycle decline in average milk yield of the multiparous cows treated with ZSO-rbST was significantly different $(P<0.05)$ from the $1.27 \mathrm{~kg} / \mathrm{d}$ per cycle decline of the multiparous control cows. Multiparous cows treated with VELrbST decreased milk yield by $1.11 \mathrm{~kg} / \mathrm{d}$ per cycle, but they did not differ from control cows (Table 2). The improvement in lactation persistency with ZSO-rbST treatment is consistent with previous observations using the same formulation (van Amburgh et al., 1997). Although van Amburgh et al. (1997) hypothesized that primiparous cows are the ones most likely to benefit 
DE MORAIS ET AL.
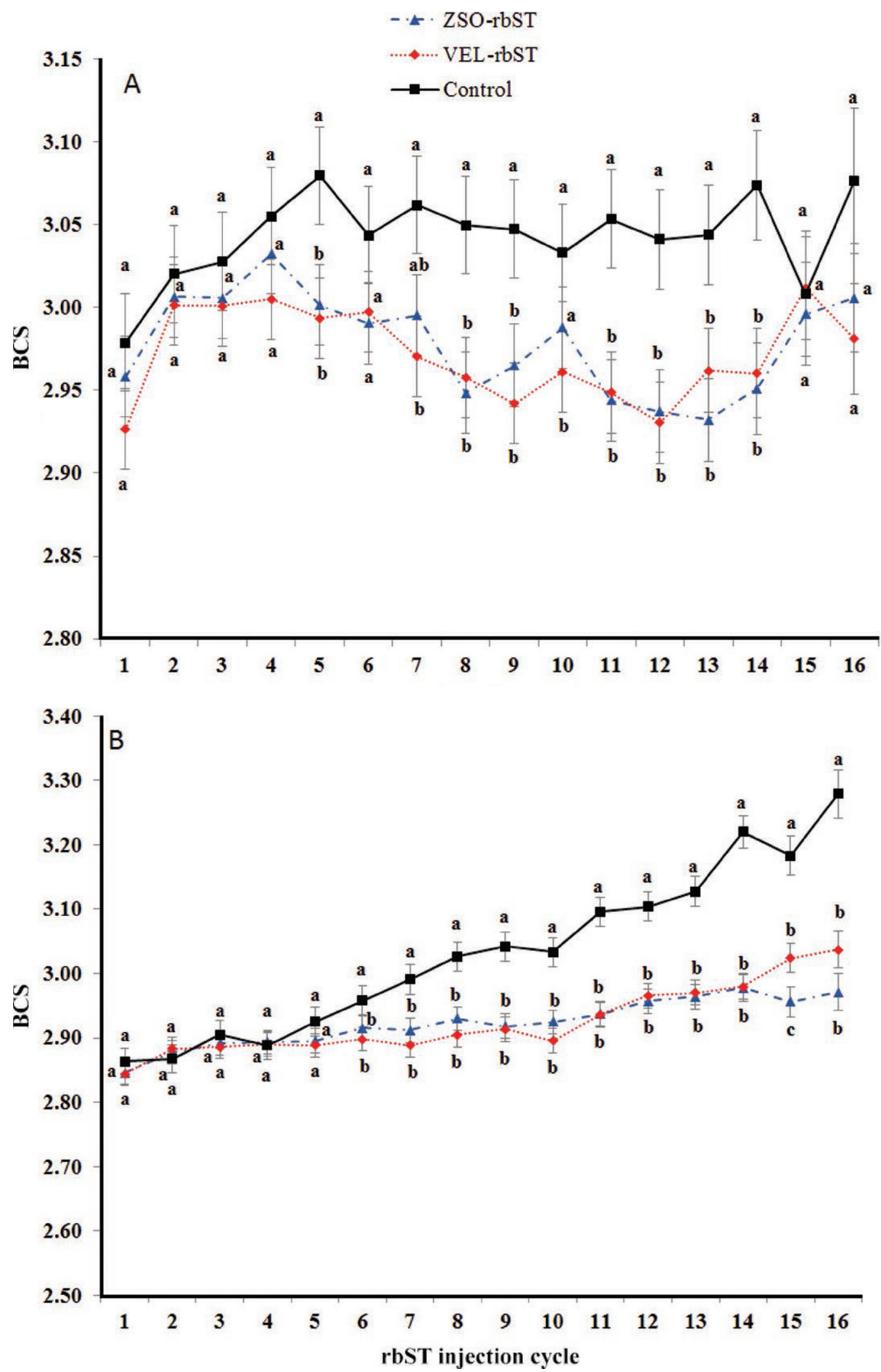

Figure 4. Least squares means and standard error of the mean of BCS (1-to-5 scale) by injection cycle for (A) primiparous and (B) multiparous cows treated with vitamin E lecithin base (VEL) and zinc sesame oil base (ZSO) recombinant bST (rbST) or not treated (control) over the 17 injection cycles. Means within a cycle with different letters $(\mathrm{a}-\mathrm{c})$ differ $(P<0.05)$. Color version available online. 
from rbST supplementation in lactation persistency, the larger standard error of the mean of the primiparous cows in the current study might have precluded us from reaching significance. These observations warrant further investigation.

Hormone release profiles for the 2 rbST formulation treatments were not performed in our study. Numerous studies demonstrate the upregulation of IGF-1 production, measured in milk and blood samples, as a primary driver to enhanced milk production in cows treated with various rbST formulations (Schams, 1989; Vicini et al., 1991; Azizan et al., 1994; Daxenberger et al., 1998; Collier et al., 2008; Castigliego et al., 2009). Azizan et al. (1994) measured blood bST and IGF-1 levels among Sahiwal Friesian dairy cows treated with the ZSO-rbST formulation and with a 14-d injection interval. The authors found greater serum bST levels up to d 14 of the cycle and greater IGF-1 levels up to d 9 of the 14-d injection cycle compared with control cows. In contrast, Castigliego et al. (2009) measured blood bST and IGF-1 levels among Italian Friesian dairy cows treated with the VEL-rbST formulation and found no blood bST or IGF-1 differences between cows treated with VEL-rbST and control cows by d 8 and 11 of the 14-d cycle, respectively. Studies that directly compare the blood rbST and IGF-1 pattern for both ZSO-rbST and VEL-rbST within a 14-d injection cycle would benefit by further exploring the differences shown by Azizan et al. (1994) and Castigliego et al. (2009).

Politis et al. (1990) demonstrated that the concentrations of milk plasmin, a serine protease involved in mammary gland involution, are significantly lower among bST-treated cows compared with controls throughout lactation. The authors further demonstrated that the effects of bST in a saline preparation on milk plasmin concentrations are very short lived, with plasmin concentrations increasing dramatically within $24 \mathrm{~h}$ after treatment cessation and a consequent decrease in milk yield. The differences in bST blood level persistency between the $2 \mathrm{rbST}$ formulations shown by Azizan et al. (1994) and Castigliego et al. (2009), and their potential effects for suppressing milk plasmin (and thus mammary gland involution), need to be studied further.

Beyond the differences in milk yield among cows treated with ZSO-rbST and those treated with VEL$\mathrm{rbST}$, it is of interest that no significant differences in BCS were found between these 2 treatments. Despite the fact that cows treated with ZSO-rbST produced more milk over the 238-d treatment period compared with those treated with VEL-rbST, both treatment groups within parity ended the lactation period with the same BCS (Figures 4A and B). Although individual animal feed intake was not measured in our study, it has been reported that cows treated with rbST increase their voluntary feed intake to support the increase in milk production and thereby maintain adequate body reserves (St-Pierre et al., 2014). An increase in voluntary feed intake is likely what happened in our study as milk production increased among cows treated with ZSO-rbST and those treated with VEL-rbST with no differential effect on BCS. In the current study, when data are analyzed by parity, it is clear that changes in BCS of the primiparous rbST-treated cows did not result in loss of BCS that the animals could not recover toward the end of lactation (Figure 4A). As for the 0.24 and 0.31 BCS difference by the end of the study for the multiparous cows in the VEL-rbST and ZSOrbST treatments, respectively, compared with control cows (Figure 4B), it has been reported that this likely represents a clinically irrelevant decrease in BW of approximately $10 \mathrm{~kg}$ (St-Pierre et al., 2014).

The lack of difference in BCS among cows treated with ZSO-rbST compared with those treated with VEL-rbST in our study was somewhat unexpected because milk production was higher for the ZSO treatment. Leonard et al. (1990) postulated that when cows are treated with $\mathrm{rbST}$, during which milk production returns to baseline and remains at that level for a period of time before rbST readministration (as observed among cows treated with VEL-rbST in our study), the strength of the biological signals driving voluntary intake may be weaker. This is consistent with the observations by Melendez and Bargo (2010), in which grazing dairy cows were administered rbST (VEL-rbST or ZSO-rbST formulation) starting at $85 \pm 11$ DIM but cows treated with the ZSO-rbST formulation had significantly higher BCS from d 154 forward in the lactation cycle compared with those treated with VEL-rbST. Similarly, a study by Fike et al. (2002) demonstrated that pasture-based cows supplemented with ZSO-rbST graze for a longer time compared with nonsupplemented cows. It is possible that the effects of rbST on feed intake depend on both rbST formulation type and feed management type. In the current study, the extra milk yield of the ZSO-rbST treatment over the VEL-rbST treatment may preclude us from seeing differences in BCS; further investigation is needed. Regardless of the differences between the $2 \mathrm{rbST}$ formulations and their potential effect on BCS, the current study showed that multiparous cows did not get thinner throughout the treatment period and that they did not regain condition as quickly as the multiparous control cows did. The latter observation could be a management strategy for reaching the dry period with a desirable BCS and preventing the potential of fat cow syndrome at calving time (Morrow, 1976). 


\section{CONCLUSIONS}

The ZSO-rbST formulation increased milk production by 2.03 and $1.32 \mathrm{~kg} / \mathrm{d}$ for primiparous and multiparous cows, respectively, when compared with the VEL-rbST formulation. Both treatments affected milk components, but the ZSO-rbST formulation resulted in greater yields of fat and protein. The greater milk yield of the ZSO-rbST formulation over the VEL-rbST formulation was attributable to less variation within the 14-d cycles as well as a more consistent response throughout the 17 injection cycles. Only the ZSO-rbST formulation was effective at increasing the lactation persistency of the treated cows compared with control cows. For dairy producers who have the choice of more than $1 \mathrm{rbST}$ formulation, this study demonstrated that the ZSO-rbST formulation is better than the VEL-rbST formulation for increasing milk yield in dairy cattle.

\section{ACKNOWLEDGMENTS}

The authors acknowledge the Universidade Federal de São Carlos (UFSCar) and Fundação de Apoio Institucional (FAI) for providing the needed staff to conduct this study and Elanco Animal Health, Greenfield, Indiana, for funding the project (FAI Grant \#23112.002298/2013-53). The authors also express their appreciation to the farm owners and staff for their cooperation.

\section{REFERENCES}

Azizan, A. R., R. H. Phipps, W. E. Wan Hassan, D. L. Hard, I. A. Forsyth, and J. A. Taylor. 1994. Concentrations of bovine somatotropin and insulin-like growth factor-I in serum and milk samples of crossbred dairy cows treated with prolonged-release bovine somatotropin. MARDI Res. J. 22:85-89.

Barbano, D. M., J. M. Lynch, D. E. Bauman, G. F. Hartnell, R. L. Hintz, and M. A. Nemeth. 1992. Effect of a prolonged-release formulation of N-methionyl bovine somatotropin (sometribove) on milk composition. J. Dairy Sci. 75:1775-1793.

Bauman, D. E. 1999. Bovine somatotropin and lactation: From basic science to commercial application. Domest. Anim. Endocrinol. $17: 101-116$.

Bauman, D. E., D. L. Hard, B. A. Crooker, M. S. Partridge, K. Garrick, L. D. Sandles, H. N. Erb, S. E. Franson, G. F. Hartnell, and R. L. Hintz. 1989. Long-term evaluation of a prolonged-release formulation of N-methionyl bovine somatotropin in lactating dairy cows. J. Dairy Sci. 72:642-651.

Branine, M., D. Döpfer, T. Edwards, C. Larson, C. Mülling, and D. Tomlinson. 2014. Cattle Lameness: Identification, Prevention and Control of Claw Lesions. 1st ed. Zinpro, Eden Prairie, MN.

Castigliego, L., G. Grifoni, R. Rosati, G. Iannone, A. Armani, D. Gianfaldoni, and A. Guidi. 2009. On the alterations in serum concentration of somatotropin and insulin-like growth factor 1 in lactating cows after the treatment with a little studied recombinant bovine somatotropin. Res. Vet. Sci. 87:29-35.

Cole, J. B., and P. M. VanRaden. 2006. Genetic evaluation and best prediction of lactation persistency. J. Dairy Sci. 89:2722-2728.
Collier, R. J., M. A. Miller, C. L. McLaughlin, H. D. Johnson, and C. A. Baile. 2008. Effects of recombinant bovine somatotropin (rbST) and season on plasma and milk insulin-like growth factors I (IGFI) and II (IGF-II) in lactating dairy cows. Domest. Anim. Endocrinol. 35:16-23.

Daxenberger, A., B. H. Breier, and H. Sauerwein. 1998. Increased milk levels of insulin-like growth factor 1 (IGF-1) for the identification of bovine somatotropin (bST) treated cows. Analyst 123:24292435.

Downer, J. V., D. L. Patterson, D. W. Rock, W. V. Chalupa, R. M. Cleale, J. L. Firkins, G. L. Lynch, J. H. Clark, B. O. Brodie, and B. F. Jenny. 1993. Dose titration of sustained-release recombinant bovine somatotropin in lactating dairy cows. J. Dairy Sci. $76: 1125-1136$

Fike, J. H., C. R. Staples, L. E. Sollenberger, J. E. Moore, and H. H. Head. 2002. Southeastern pasture-based dairy systems: Housing, Posilac, and supplemental silage effects on cow performance. J. Dairy Sci. 85:866-878.

Huber, J. T., Z. Wu, C. Fontes, J. L. Sullivan, R. G. Hoffman, and G. F. Hartnell. 1997. Administration of recombinant bovine somatotropin to dairy cows for four consecutive lactations. J. Dairy Sci. 80:2355-2360.

Kenward, M. G., and J. H. Roger. 1997. Small sample inference for fixed effects from restricted maximum likelihood. Biometrics 53:983-997.

Leonard, M., M. Gallo, G. Gallo, and E. Block. 1990. Effects of a 28day sustained-release formulation of recombinant bovine somatotropin (rbST) administered to cows over two consecutive lactations. Can. J. Anim. Sci. 70:795-809.

McGuire, M. A., J. L. Vicini, D. E. Bauman, and J. J. Veenhuizent. 1992. Insulin-like growth factors and binding proteins in ruminants and their nutritional regulation. J. Anim. Sci. 70:2901-2910.

Melendez, P., and F. Bargo. 2010. Release of recombinant bovine somatotropin affects body condition in grazing dairy cows of Chile. Page 258 in XXVI World Buiatrics Congress 2010, Santiago, Chile. Chilean Buiatrics Society, Santiago, Chile.

Morrow, D. A. 1976. Fat cow syndrome. J. Dairy Sci. 59:1625-1629.

NRC. 2001. Nutrient Requirements of Dairy Cattle. 7th rev. ed. National Academies Press, Washington, DC.

Pennington, J. 2003. Body Condition Scoring With Dairy Cattle. University of Arkansas Division of Agriculture Cooperative Extension Service, Fayetteville.

Politis, I., E. Block, and J. D. Turner. 1990. Effect of somatotropin on the plasminogen and plasmin system in the mammary gland: Proposed mechanism of action for somatotropin on the mammary gland. J. Dairy Sci. 73:1494-1499.

SAS Institute Inc. 2011. SAS/Stat 9.3. User's Guide. SAS Institute Inc., Cary, NC.

Schams, D. 1989. Somatotropin and related peptides in milk. Pages 192-200 in Use of Somatotropin in Livestock Production. K. Sejrsen, M. Vestergaard, and A. Neimann-Sorensen, ed. Elsevier Applied Science, New York, NY.

St-Pierre, N. R., G. A. Milliken, D. E. Bauman, R. J. Collier, J. S. Hogan, J. K. Shearer, K. L. Smith, and W. W. Thatcher. 2014. Meta-analysis of the effects of sometribove zinc suspension on the production and health of lactating dairy cows. J. Am. Vet. Med. Assoc. 245:550-564.

Tauer, L. W. 2016. The effect of bovine somatotropin on the cost of producing milk: Estimates using propensity scores. J. Dairy Sci. 99:2979-2985.

van Amburgh, M. E., D. M. Galton, D. E. Bauman, and R. W. Everett. 1997. Management and economics of extended calving intervals with use of bovine somatotropin. Livest. Prod. Sci. 50:15-28.

Vicini, J. L., F. C. Buonomo, J. J. Veenhuizen, M. A. Miller, D. R. Clemmons, and R. J. Collier. 1991. Nutrient balance and stage of lactation affect responses of insulin, insulin-like growth factors I and II, and insulin-like growth factor-binding protein 2 to somatotropin administration in dairy cows. J. Nutr. 121:1656-1664. 